American Journal of Cardiology Research and Reviews
(ISSN:2637-4935)

\title{
Role of Mesenchymal Stem Cells in Cardiovascular Disease
}

Dr. Vikram Aiman Ayapathi ${ }^{1}$, Dr. Ayapati Gautam Mehdi ${ }^{1}$, Wajeeda Tabassum ${ }^{1}$, Dr. Aleem Ahmed Khan ${ }^{2^{*}}$, Dr. Roya Rozati ${ }^{3}$

${ }^{1}$ Research Scholar, Maternal Health and Research Trust(MHRT), Banjara Hills,Hyderabad-34, India. ${ }^{2}$ Scientist, Central Research Laboratory, CLRD, Deccan College of Medical Sciences, Owaisi Hospital \& Research Centre Kanchanbagh, Hyderabad 500058, Telangana, India. ${ }^{3}$ MD (A.I.I.M.S, Delhi), F.R.C.O.G.(London), Professor and Head,Dept of Obst \&Gynecology, Shadan Institute of Medical Sciences, Member Secretary, Maternal Health and Research Trust(MHRT), Banjara Hills,Hyderabad-34, India.

\section{ABSTRACT}

In recent years, globally there is an incredible boost in stem cell research has kindled the expectations of both patients and physicians. Mesenchymal stem cells (MSCs) seem to represent a future powerful tool in regenerative medicine, owing to their availability, ease of manipulation, and therapeutic potential, therefore they are particularly important in medical research. Mesenchymal stem cells (MSCs) are capable self-renewing, multipotent progenitor cells with multilineage potential to differentiate into cell types, such as adipocytes, cardiomyocytes, endothelial cells and vascular smooth muscle cells, although the relative contribution of trilineage differentiation and paracrine effectors on cardiac repair. MSCs shows to have the beneficial effects of MSC-based therapies offers most attractive options to treatment of wide range of diseases from cartilage defects to cardiac disorders. Cardiovascular diseases (CVDs) are an important cause of death and disease worldwide. Because injured cardiac tissue cannot be repaired itself, it is urgent to develop other alternate therapies. Stem cells can be differentiated into cardiomyocytes, endothelial cells, and vascular smooth muscle cells for the treatment of CVDs. In addition to cardiac stem cells, mesenchymal stem cells represent another multipotent cell population in the heart; these cells are located in regions near pericytes and exhibit regenerative, angiogenic, antiapoptotic, and immunosuppressive properties.

Keywords: Adult stem cells(ASc), tissue-specific resident stem cells (TSCs), Mesenchymal stromal cells (MSCs), Induced pluripotent stem cells (iPSCs) Embryonic stem cells (ESCs) Heart Failure (HF)

*Correspondence to Author:

Dr. Aleem Ahmed Khan

Scientist, Central Research Laboratory, CLRD, Deccan College of Medical Sciences, Owaisi Hospital \& Research Centre, Kanchanbagh, Hyderabad 500058, Telangana, India.

How to cite this article:

Vikram Aiman Ayapathi, Ayapati Gautam Mehdi, Wajeeda Taba -ssum, Aleem Ahmed Khan, Roya Rozati. Role of Mesenchymal Stem Cells in Cardiovascular Disease. American Journal of Cardiology Research and Reviews, 2021, 4:13.

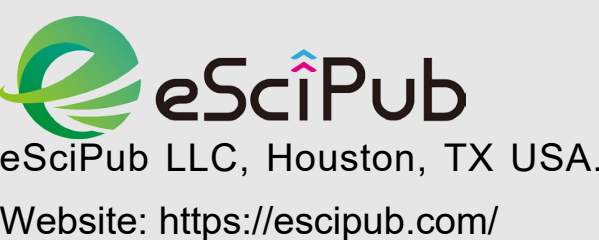

Website: https://escipub.com/ 


\section{Background}

Adult stem cells are activated to proliferate and differentiate during normal tissue homeostasis as well as in disease states and injury, which will help in in the restoration of function to damaged tissue via either complete or partial regeneration. Mesenchymal stromal cells (MSCs) and tissuespecific resident stem cells (TSCs) plays an important role in Tissue repair process and regeneration or the formation of scar tissue follows an injury respectively. TSCs and MSCs are crucial for complex cascade of signals regulating both cell populations, emerged as potential therapeutic targets to treat reparative disorders.

\section{Introduction}

Tissue repairs post-injury or during disease culminates in either complete restoration of tissue integrity, defined here as regeneration, or in a process that leads to the generation of stromal structures that replace functional tissue. Regeneration of tissues is typically accompanied by acute or chronic inflammation caused by the disease or trauma, and involves the coordinated interaction among multiple cell types, including tissue specific stem/ progenitor cells (TSCs), mesenchymal stromal cells (MSCs) and immune cells.It is due to aberrant environmental cues and alterations of the signaling networks between these cells are central to the establishment of reparative disorders. ${ }^{[1]}$

\section{Mesenchymal Stem Cells (MSCs)}

Mesenchymal stem cells (MSCs), also referred to as mesenchymal stromal cells, are adult stem cells capable of self-renewal and multilineage differentiation [2]. Mesenchymal stem cells (MSCs) are nonhematopoietic cells, which reside in the bone marrow ${ }^{[3]}$ populating cells. MSCs are the functional part of bone marrowderived stem/progenitor cells that can promote cardiac muscle repair after injury. MSCs may exhibit different characteristics depending on their tissue of origin, they must meet the three minimal criteria based on International Society for Cellular Therapy (ISCT) ${ }^{[4]}$. Firstly, it shows plastic-adherence when grown in vitro, secondly must express the surface antigens and third, MSCs must differentiate into mesodermal cell types (i.e., adipocytes, chondrocytes, and osteoblasts) when cultured under specific conditions. It possesses an extensive proliferative potential and ability to differentiate into mesodermal and nonmesodermal origin (ectodermal and endodermal lineages) various cell types, including osteocytes, adipocytes, chondrocytes, myocytes, cardiomyocytes and neurons ${ }^{[5,6,7,8]}$.

Mesenchymal stem cells (MSCs), also referred to as mesenchymal stromal cells, are adult stem cells capable of self-renewal, multilineage differentiation ${ }^{[2]}$ and immunomodulatory properties. Their two most attractive features are plasticity and tropism. MSCs are pluripotent $T$ cells that have self-renewing, differentiation, and immunomodulatory properties. Their two most attractive features are plasticity and tropism. In the table 1 shows the advantages and disadvantages of MSCs.

It plays a central role in tissue repair in addition to their antitumorigenic, antifibrotic, antiapoptotic, anti-inflammatory, proangiogenic, neuroprotective, antibacterial, and chemo attractive effects $[9,10]$. This unique set of characteristics makes MSCs attractive for their therapeutic potential in the fields of regenerative medicine [11], inflammatory disorders ${ }^{[9]}$, and, increasingly, cancer therapy ${ }^{[12]}$.

In mammals, cardiac damage is not followed by the complete replacement of lost cellular components but is rather defined by a relatively minor capacity for regeneration and far more robust reparative response. Lacking an ability to regenerate, the formation of a scar in a timely manner following cardiac damage or during cardiac disease is critical in allowing continued organ functionality. The heart harbour's its own population of TSCs, the cardiac stem cells ${ }^{[13,14]}$, which account for the limited regenerative capacity of this organ, which is similar to other organs, its repair processes may be governed by a cardiac-resident population of MSCs.

\section{Sources of MSCs}

The main source of MSCs is the bone marrow which constitutes, however, only a small percentage of the total number of bone marrow populating cells. About $0.01 \%$ to $0.001 \%{ }^{[15]}$ of ournal-of-cardiology-research-and-reviews/ 
mononuclear cells isolated on density gradient (ficoll/percoll) give rise to plastic adherent fibroblast like colonies. MSCs may generate upon appropriate stimulation quite different mature cells including osteoblasts, chondrocytes, tenocytes, adipocytes, smooth muscle cells, and stromal cells of the bone marrow ${ }^{[16]}$.

Mesenchymal stromal cells can be isolated from many different adult tissues, including bone marrow, adipose tissue ${ }^{[17]}$ inner organs, and blood vessels described in Figure 1 and from rather "young sources" such as amniotic fluid, amniotic membrane, umbilical cord, or placenta $[18,19,20,21$, 22, 23, 24,25].

The amount of MSCs decreases with age ${ }^{[26]}$ and infirmity. The greatest number of MSCs is found in neonates, then it is reduced during the lifespan to about one-half at the age of 80 .

MSCs have recently been gaining significant attention, owing to some of their unique properties and their feasibility of use as an "unlimited" offthe-shelf source of regenerative cells but they exhibit several differences ${ }^{[27,28]}$. It displays differentiation capacities and therefore qualify as multipotent progenitor cell. It may reflect particular regional properties of the niches from which they originate the cell source ${ }^{[29,30]}$ and are susceptible to variations in cell culture conditions and isolation protocols $[31,32,33]$

\section{Cardiovascular disease}

The increase in the average human lifespan has been accompanied by an increased incidence of chronic diseases [34]. These chronic non-communicable diseases are the result of a number of risk factors and are characterized by a prolonged natural course and the potential for developmental disabilities. Globally there is a health concern regarding cardiovascular diseases (CVD) are the number one cause of high morbidity and mortality rates globally,than any other single disease [35]. It is estimated 17.9 million people died from CVDs in 2019, representing $32 \%$ of all global deaths. CVDs affect not only elderly people but also middle-aged people at the peak of their working and social capacities; hence, CVDs are an enormous medical and economic problem in society. Of these deaths, $85 \%$ were due to heart attack and stroke ${ }^{[36]}$ Common causes of heart failure is ischemia, hypertension, coronary artery disease and idiopathic dilated cardiomyopathy.

MSC-based therapies provide the treatment of cardiovascular disease represent a substantial proportion and exhibit extremely promising therapeutic significance. Stem cell-based therapy aimed at regenerating damaged myocardium is an emerging treatment modality. There is Growing evidence indicates that exosomes derived from ESCs, iPSCs, and MSCs have the effects of inducing cardiomyocyte proliferation, promoting angiogenesis, reducing apoptosis, and inhibiting fibrosis and may be used for myocardial protection and treatment ${ }^{[37,38]}$.

Table 1 illustrates the Advantages and disadvantages of stem cell (SC) types used for cardiac regeneration

\begin{tabular}{|l|l|l|}
\hline Cell type & Advantages & Disadvantages \\
\hline MSCs & Easy access from several tissues & Limited cell quantity \\
\hline & Low ethical concerns & Limited differentiation potential \\
\hline & $\begin{array}{l}\text { Transplantation of autologous and allogenic cells } \\
\text { due to low immunogenicity }\end{array}$ & Undefined in situ phenotype \\
\hline & Proof of safety in clinical trials & Heterogeneous cell population \\
\hline & Rapid in vitro expansion & Inconsistent results regarding therapeutic effects \\
\hline & Therapeutic secretome & \\
\hline & Beneficial immunomodulative properties & \\
\hline & Low risk of tumorigenicity & \\
\hline
\end{tabular}

AJCRAR: https://escipub.com/american-journal-of-cardiology-research-and-reviews/ 


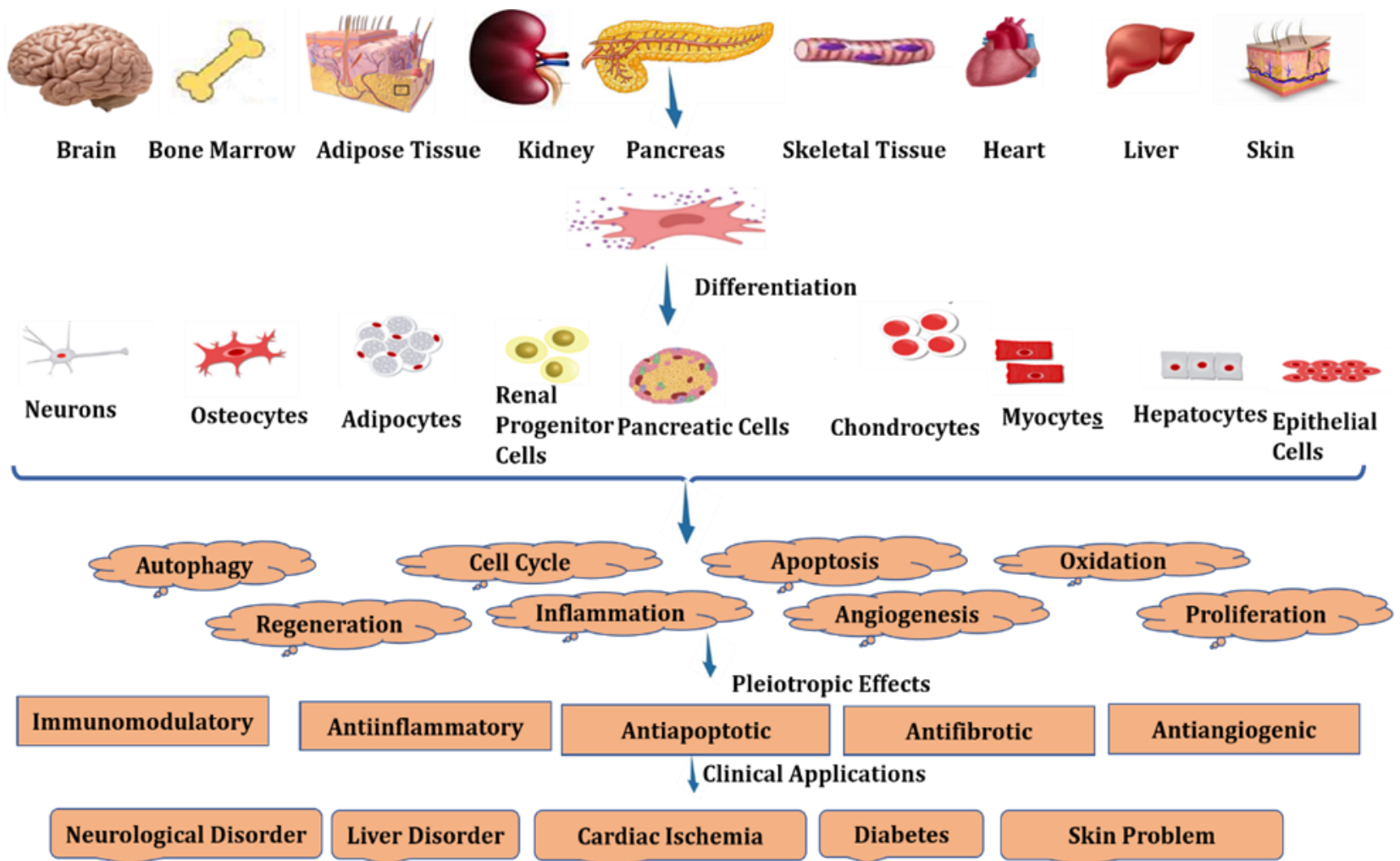

Figure 1. Schematic Representation of Source of Mesenchymal Stem Cells-And their use in Clinical Application-Differentiation of MSCs from various tissues (bone marrow (BM), brain, heart,liver , skin , kidney , Pancreas and adipose tissue), skeletal have been applied to stimulate cardiac regeneration of the adult heart in pre-clinical and clinical studies. Their mechanistic actions, pleiotropic effects and usage in Clinical Applications.

Myocardial infarction (MI) leads to a massive loss of functional cardiomyocytes which is a major cause of human death worldwide. Though pharmacotherapy, thrombolysis, coronary stent implantation, and coronary artery bypass grafting have been clinically used to treat $\mathrm{Ml}$ and improve patients' survival, these methods cannot fundamentally repair the damaged heart and restore heart function. Stem cell transplantation is considered as a promising way to treat $\mathrm{Ml}$, which has made significant progress in preclinical and clinical studies recently. Stem cell candidates mainly include two categories: (I) pluripotent stem cells (embryonic stem cell and induced pluripotent stem cells) and their derivatives and (2) adult stem cells, including hematopoietic stem cells and mesenchymal stem cells (MSCs) ${ }^{[5]}$. MSCs are mesoderm-derived multipotent stromal cells that reside in embryonic and adult tissues, having the capacity for self-renewal, immune privilege, immunomodulation, and low tumorigenicity

MSCs exerts cardiovascular diseases with immunoregulatory ability, antifibrotic effect, and neovascularization features. It plays an important role in therapeutic function in cardiovasculardiseases primarily through paracrine activities. Myocardial infarction is an acute or chronic blockage of the coronary arteries that causes apoptosis and necrosis in cardiomyocytes. Myocardial infarction is an irreversible injury and the leading cause of death in patients with CVDs ${ }^{[39]}$. Cardiomyocytes are potently injured in the disease and appear to be the most critical cell type that requires effective regeneration or recovery from severe dysfunction to result in a successful therapy ${ }^{[40]}$. The role of MSCs in myocardial regeneration is their synthesis and secretion of cytokines and other trophic growth factors to signal to the injured myocardial cells ${ }^{[41]}$ which may also involve anti-aging effects ${ }^{[42,43,44]}$.

Myocardial infarction was characterized by a reduction in apoptotic myocytes and an augmentation of vascularity ${ }^{[45,46]}$. Scar tissue reduction and cardio protection after MSC transplantation have been well studied. 


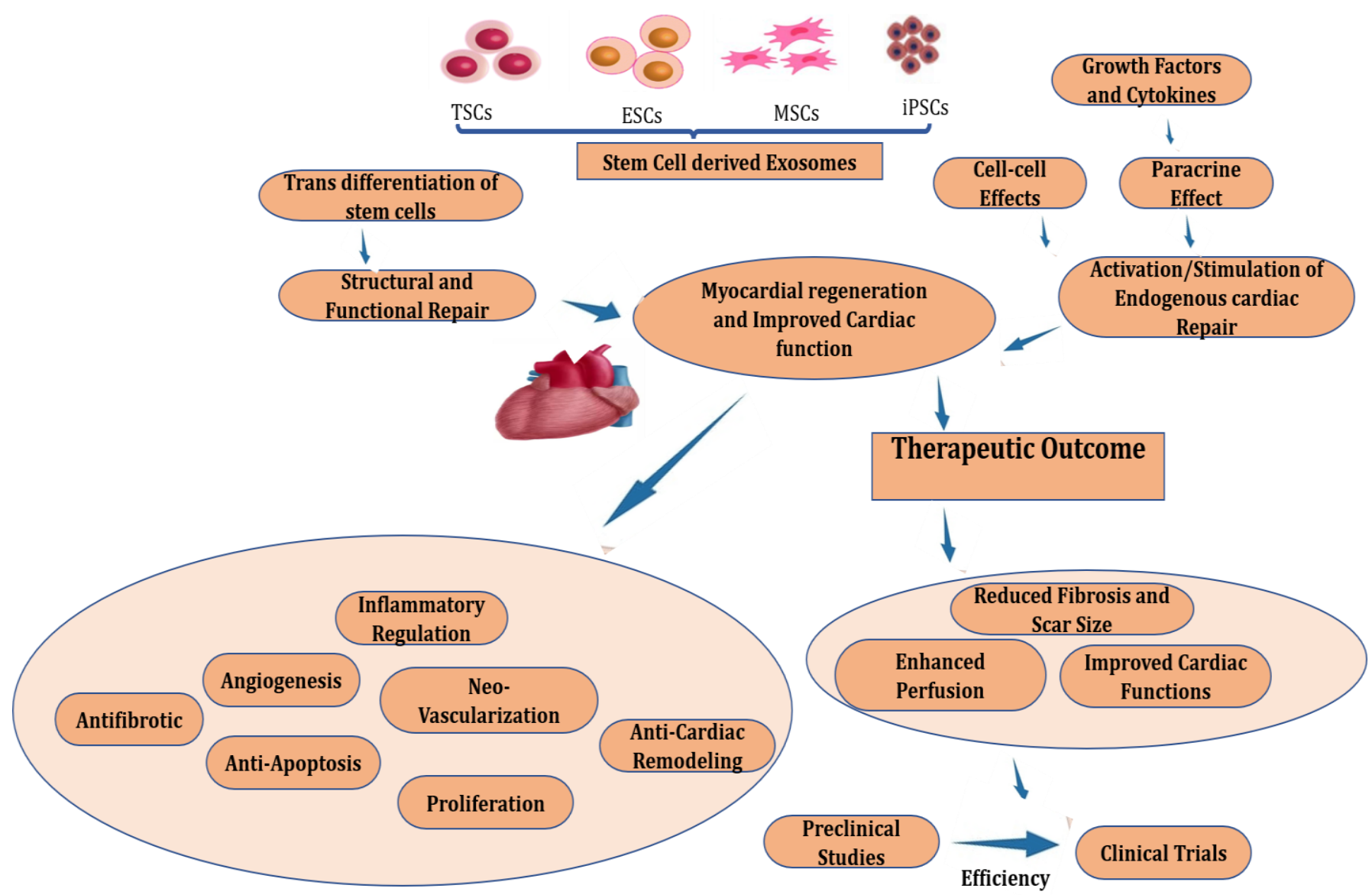

Figure 2: Mechanism of Stem Cell therapy for myocardial regeneration and improvement of cardiac function. Exosomes derived from stem cells promote cardiomyocyte survival, anti-apoptosis, proliferation and cardiovascular production, Antifibrotic, anti-inflammatory, neovascularization thereby repairing CVDs tissue. TSCs (Totipotent stem cells) ESCs (embryonic stem cells), iPSCs (induced pluripotent stem cells), MSCs, (mesenchymal stem cells). Cardiac healing and repair mediated by direct and indirect mechanisms in cardiac cell therapy

\section{Cardiac Mesenchymal Stem Cells}

The class of multipotent cells present in the heart are cardiac mesenchymal stem cells (cMSCs), which have been referred to in the literature as cardiac mesenchymal stem-like cells ${ }^{[47]}$ and cardiac mesenchymal-like stromal cells ${ }^{[48]}$. MSCs were initially derived from the plasticadherent fraction of components of mononuclear cells isolated by density-gradient centrifugation of bone marrow cells and culturing on an adherent surface MSCs have since been derived from many organs other than bone marrow ${ }^{[5]}$ and were recently, identified in the cardiac stroma ${ }^{[49]}$. The phenotypic characterization of this cell type is complex, and there is not a specific marker or combination of markers to identify MSCs ${ }^{[50]}$. In culture, the phenotype of MSCs is altered; the surface markers of freshly isolated mesenchymal cells differ from those maintained in culture for a long period ${ }^{[51]}$. MSCs are usually defined based on a combination of physical, morphological, phenotypic, and functional properties The following minimal criteria have been established for the identification of MSCs: (i) adherence to plastic; (ii) adipogenic, chondrogenic, and osteogenic differentiation capacities; (iii) expression of CD73, CD90 and CD105 and the absence of surface markers such as CD45, CD34, CD11b and CD14, CD79a or CD19 and HLADR.; and (iv) ability to generate colony-forming unit fibroblast.

In contrast to other stem cells present in the heart, MSCs lose their multipotentiality with passage in culture and enter senescence ${ }^{[50]}$, which means that the growth potential of these cells is limited

In the heart, the CSCs are organized in niches that are preferentially allocated in the atrium and ventricular apex, areas that are protected because they are exposed to low levels of 
hemodynamic stress. These niches are connected by supporting cells, such as fibroblasts and myocytes, highlighting the importance of connexins and cadherins, which play roles in the formation of gap junctions and adherens junctions at the interfaces of these different cell types [52,53]. In MI the niche is comprised of supporting cells and cell-cell interactions that have crucial regulatory roles. It triggers chemokine and cytokine cascades that initiate and boost an endogenous repair mechanism through the restoration of a cellular and molecular collective with the properties ${ }^{[54]}$.

The cardiac progenitor/stem cells appear to represent an attractive option for use in clinical trials because they are intrinsically more likely to possess all of the characteristics required to repair the damaged heart ${ }^{[55]}$ and improve cardiac function after myocardial injury [34].

\section{Therapeutic Potential of MSCS with MI}

Over the past decades, a large number of studies have emerged using MSC-based therapies in preclinical studies to treat many different pathologies, including neurological disorders, cardiac ischemia, diabetes and bone and cartilage diseases $[56,57,58,59,60,61]$. MSC therapy is an attractive candidate for cardiovascular repair due to its regenerative and immunomodulatory properties. It is mediated by their inherent ability to migrate toward damaged tissues. Then, engrafted cells secrete bioactive mediators, such as growth factors, cytokines and extracellular vesicles that exert immunosuppressive, antiapoptotic, antifibrotic, angiogenic, and anti-inflammatory effects ${ }^{[62]}$. The therapeutic potential of these cells stems from several properties, including their ability to i) differentiate into various cell lineages, ii) secrete soluble factors crucial for cell survival and proliferation, iii) modulate immune response, and iv) migrate to the exact site of injury. The present therapeutic interventions, including traditional medicine, devices, and surgical therapies, have therapeutic effects on heart failure (HF); however, further revascularization and medical therapy may be useless because the ventricular remodelling process is usually irreversible in end stage HF patients

\section{Discussion}

Transplantation of bone-marrow derived stem/progenitor cells has an established therapeutic effect on cardiac muscle repair after injury. Neovascularization is critical for tissue repair, and thus examined the angiogenic factors in MSCs for promoting neovascularization.

The therapeutic benefits of MSCs could be partially stemmed from their modulation of inflammation response, since after MSCs treatment, the features and properties of macrophages in the injured heart was significantly changed, while the macrophage phenotypic changes are more likely appearing a M2-like alteration. Compared to M1, M2 macrophages have less proinflammatory potential, but produce and release many cytokines and growth factors to improve cell survival, proliferation, and to reduce cellular apoptosis ${ }^{[63]}$. stem and progenitor cells located in the myocardium ${ }^{[64]}$ identified the human adult heart as an organ bearing potential for self-renewal. However, the limited endogenous degree of cardiac regeneration is insufficient to compensate for the massive loss of cardiomyocytes occurring after acute injury and the consecutive adverse remodelling.

\section{Conclusions}

MSCs have raised the substantial interest due to its potentiality and versatilityto expand for extended periods of time without losing their original characteristics highlights them for use in celland gene-based therapies. Stem cell therapy is a novel and promising therapeutic modality for patients with significant cardiac dysfunction.MSCs are ideal for the treatment for $\mathrm{MI}$ as they repair or induce the repair of damaged organs, their pleiotropic activity and the technical ease of manipulation. MSCs have emerged as a promising therapeutic strategy because of their tropism for other cell types as well as their immunomodulatory functions and migrate toward sites of inflammation. The transplantation of SCs emerged as a new approach to restore damaged myocardial tissue.They were identified as the cells that would change regenerative medicine via their ability to differentiate into end-cell lines, allowing the shortage of donor organs to become 
a nonfactor in treatment of many endsstage disease state. MSCs have many clinical applications, with an important role in almost all medical and surgical specialties. MSCs will play an important role in managing many disorders that lack effective standard treatment. Novel delivery of MSCs as therapeutics in HF can overcome many of the current pitfalls such as hostile environment of HF for regenerative medicine and retention of cells

\section{Author Contributions}

V.A.A., W.T., and RR.: manuscript writing, final approval of the manuscript.

\section{Conflict of interest:}

No potential conflict of interest relevant to this article is reported

\section{Acknowledgments}

We would like to thank Dr. Roya Rozati for her support and guidance

\section{References}

[1] Moyer AL, Wagner KR. Regeneration versus fibrosis in skeletal muscle. CurrOpinRheumatol. 2011, 1;23(6):568-73.

http://doi.org/10.1097/BOR.0b013e32834bac 92

[2] Jiang $Y$, Jahagirdar BN, Reinhardt RL, Schwartz RE, Keene CD, Ortiz-Gonzalez XR, Reyes M, Lenvik $T$, Lund $T$, Blackstad $M$, Du J. Pluripotency of mesenchymal stem cells derived from adult marrow. Nature. 2002 Jul;418(6893):41-9. http://doi.org/10.1038/nature00870

[3] Friedenstein AJ, Chailakhjan RK, Lalykina K. The development of fibroblast colonies in monolayer cultures of guinea - pig bone marrow and spleen cells. Cell Tissue Kinet1970 Oct;3(4):393-403.

http://doi.org/10.1111/j.1365-

2184.1970.tb00347.x.

[4] Dominici ML, Le Blanc K, Mueller I, Slaper-Cortenbach I, Marini FC, Krause DS, Deans RJ, Keating A, Prockop DJ, Horwitz EM. Minimal criteria for defining multipotent mesenchymal stromal cells. The International Society for Cellular Therapy position statement.

[5] Meirelles LD, Chagastelles PC, Nardi NB. Mesenchymal stem cells reside in virtually all post-natal organs and tissues. J Cell Sci. 2006 Jun 1;119(Pt 11):2204-13.http://doi.org/ 10.1242/jcs.02932.

[6] Paunescu V, Deak E, Herman D, Siska IR, T` anasie G, Bunu C, Anghel S, Tatu CA, Oprea TI, Henschler R, Rüster $B$. In vitro differentiation of human mesenchymal stem cells to epithelial lineage. J Cell Mol Med May-Jun 2007;11(3):502-8.

http://doi.org/10.1111/j.1582-

4934.2007.00041.x

[7] Quevedo HC, Hatzistergos KE, Oskouei BN, Feigenbaum GS, Rodriguez JE, Valdes D, Pattany PM, Zambrano JP, Hu Q, McNiece I, Heldman AW. Allogeneic mesenchymal stem cells restore cardiac function in chronic ischemic cardiomyopathy via trilineage differentiating capacity. Proc Natl Acad Sci U S A. 2009 Aug 18;106(33):140227. http://doi.org/10.1073/pnas.0903201106.

[8] Gervois P, Struys T, Hilkens P, Bronckaers A, Ratajczak J, Politis C, Brône B, Lambrichts I, Martens W. Neurogenic maturation of human dental pulp stem cells following neurosphere generation induces morphological and electrophysiological characteristics of functional neurons. Stem Cells Dev. 2015 Feb 1;24(3):296-311. http://doi.org/ $10.1089 / \mathrm{scd} .2014 .0117$

[9] Galipeau J, Sensébé L. Mesenchymal stromal cells: clinical challenges and therapeutic opportunities. Cell Stem Cell. 2018 Jun 1;22(6):824833.http://doi.org/ 10.1016/j.stem.2018.05.004.

[10] Timaner M, Tsai KK, Shaked Y. The multifaceted role of mesenchymal stem cells in cancer. Semin Cancer Biol 2020 Feb;60:225-237

[11]Chen Y, Shao JZ, Xiang LX, Dong XJ, Zhang GR. Mesenchymal stem cells: a promising candidate in regenerative medicine. The international journal of biochemistry \& cell biology. 2008 Jan 1;40(5):81520.

http://doi.org/ 10.1016/j.semcancer.2019.06.003.

[12] Dai LJ, Moniri MR, Zeng ZR, Zhou JX, Rayat J, Warnock GL. Potential implications of mesenchymal stem cells in cancer therapy. Cancer Lett. 2011 Jun 1;305(1):8-20.http://doi.org/ 10.1016/j.canlet.2011.02.012.

[13] Nesti LJ, Jackson WM, Shanti RM, Koehler SM, Aragon AB, Bailey JR, Sracic MK, Freedman BA, Giuliani JR, Tuan RS. Differentiation potential of multipotent progenitor cells derived from war-traumatized muscle tissue. J Bone Joint Surg Am. 2008;90:2390-8.

http://doi.org/10.2106/jbjs.h.00049

[14] Jackson WM, Aragon AB, Bulken - Hoover JD, Nesti LJ, Tuan RS. Putative heterotopic ossification progenitor cells derived from traumatized muscle. J Orthop Res. 2009 December ; 27(12): 16451651. http://doi.org/10.1002/jor.20924

[15] Pittenger MF, Discher DE, Péault BM, Phinney DG, Hare JM, Caplan AI. Mesenchymal stem cell perspective: cell biology to clinical progress. NPJ Regen Med. 2019 Dec 2;4:22. http://doi.org/10.1038/s41536-019-0083-6 
[16] Caplan Al. Mesenchymal stem cells: cell-based reconstructive therapy in orthopedics. Tissue Eng. Jul-Aug 2005;11(7-8):1198-21. http://doi.org/ 10.1089/ten.2005.11.1198.

[17]Zuk PA, Zhu MI, Mizuno H, Huang J, Futrell JW, Katz AJ, Benhaim P, Lorenz HP, Hedrick MH. Multilineage cells from human adipose tissue: implications for cell-based therapies. Tissue Eng. 2001 Apr;7(2):211-28.://doi.org/ 10.1089/107632701300062859

[18] De Coppi P, Callegari A, Chiavegato A, Gasparotto L, Piccoli M, Taiani J, Pozzobon M, Boldrin L, Okabe M, Cozzi E, Atala A. Amniotic fluid and bone marrow derived mesenchymal stem cells can be converted to smooth muscle cells in the cryo-injured rat bladder and prevent compensatory hypertrophy of surviving smooth muscle cells. J Urol. 2007 Jan;177(1):369-7. http://doi.org/ 10.1016/j.juro.2006.09.103.

[19] Anker PS, Scherjon SA, Kleijburg - van der Keur C, de Groot - Swings GM, Claas FH, Fibbe WE, Kanhai $\mathrm{HH}$. Isolation of mesenchymal stem cells of fetal or maternal origin from human placenta. Stem cells. 2004 Dec;22(7):1338-45.http://doi.org/ 10.1634/stemcells.2004-0058.

[20]Lee OK, Kuo TK, Chen WM, Lee KD, Hsieh SL, Chen $\mathrm{TH}$. Isolation of multipotent mesenchymal stem cells from umbilical cord blood. Blood. 2004 Mar 1;103(5):1669-75. http://doi.org/10.1182/blood-2003-05-1670

[21]Bieback K, Kern S, Klüter H, Eichler H. Critical parameters for the isolation of mesenchymal stem cells from umbilical cord blood. Stem cells. 2004 Jul;22(4):625-34. http://doi.org/ 10.1634/stemcells.22-4-625.

[22] Limbert C, Ebert R, Schilling T, Path G, Benisch P, Klein-Hitpass L, Seufert J, Jakob F. Functional signature of human islet-derived precursor cells compared to bone marrow-derived mesenchymal stem cells. Stem Cells Dev. 2010 May;19(5):679-91. http://doi.org/ 10.1089/scd.2009.0241.

[23] Covas DT, Panepucci RA, Fontes AM, Silva Jr WA, Orellana MD, Freitas MC, Neder L, Santos AR, Peres LC, Jamur MC, Zago MA. Multipotent mesenchymal stromal cells obtained from diverse human tissues share functional properties and geneexpression profile with CD146+ perivascular cells and fibroblasts. Exp Hematol. 2008 May;36(5): 642-54.

http://doi.org/10.1016/j.exphem.2007.12.015

[24] Parolini O, Alviano F, Bagnara GP, Bilic G, Bühring $\mathrm{HJ}$, Evangelista M, Hennerbichler S, Liu B, Magatti M, Mao N, Miki T. Concise review: isolation and characterization of cells from human term placenta: outcome of the first international Workshop on Placenta Derived Stem Cells. Stem cells. 2008 Feb;26 (2):300-11. http://doi.org/10.1634/stemcell.200 7-0594.

[25]Pilz GA, Ulrich $C$, Ruh $M$, Abele $H$, Schäfer R, Kluba T, Bühring HJ, Rolauffs B, Aicher WK. Human term placenta-derived mesenchymal stromal cells are less prone to osteogenic differentiation than bone marrow-derived mesenchymal stromal cells. Stem Cells Dev. 2011 Apr;20(4):63546.http://doi.org/ 10.1089/scd.2010.0308

[26] Fibbe WE, Noort WA. Mesenchymal stem cells and hematopoietic stem cell transplantation. Ann N Y Acad Sci. 2003 May;996:235-44. http://doi.org/10.1111/j.1749-

6632.2003.tb03252.x

[27] Wang HS, Hung SC, Peng ST, Huang CC, Wei HM, Guo YJ, Fu YS, Lai MC, Chen CC. Mesenchymal stem cells in the Wharton's jelly of the human umbilical cord. Stem cells. 2004 Dec;22(7):1330-7. http://doi.org/ 10.1634/stemcells.2004-0013.

[28] Musialek P, Mazurek A, Jarocha D, Tekieli L, Szot $W$, Kostkiewicz $M$, Banys RP, Urbanczyk $M$, Kadzielski A, Trystula M, Kijowski J. Myocardial regeneration strategy using Wharton's jelly mesenchymal stem cells as an off-the-shelf unlimited'therapeutic agent: results from the Acute Myocardial Infarction First-in-Man Study. PostepyKardiollnterwencyjnej. 2015;11(2):100-7. http://doi.org/ 10.5114/pwki.2015.52282

[29] Ayatollahi M, Talaei-Khozani T, Razmkhah M. Growth suppression effect of human mesenchymal stem cells from bone marrow, adipose tissue, and Wharton's jelly of umbilical cord on PBMCs. Iran J Basic Med Sci 2016;19:145-153.

[30] Karaöz E, Demircan PÇ, Erman G, Güngörürler E, Sarıboyacı AE. Comparative analyses of immunosuppressive characteristics of bone-marrow, Wharton's jelly, and adipose tissue-derived human mesenchymal stem cells. Turk J Haematol. 2017 Aug 2;34(3):213-225 .

http://doi.org/ 10.4274/tjh.2016.0171

[31] Fuchs E, Tumbar T, Guasch G. Socializing with the neighbors: stem cells and their niche. Cell. 2004 Mar 19;116(6):769-78.

http://doi.org/ 10.1016/s0092-8674(04)00255-7

[32] Amable PR, Teixeira MV, Carias RB, Granjeiro JM, Borojevic R. Protein synthesis and secretion in human mesenchymal cells derived from bone marrow, adipose tissue and Wharton's jelly. Stem Cell Res Ther. 2014 Apr 16;5(2):53. http://doi.org/ 10.1186/scrt442.

[33] Amable PR, Teixeira MV, Carias RB, Granjeiro JM, Borojevic R. Mesenchymal stromal cell proliferation, gene expression and protein production in 
human platelet-rich plasma-supplemented media. PloS one. 2014 Aug 12;9(8):e104662.

http://doi.org/10.1371/journal.pone.0104662

[34] Torella D, Ellison GM, Karakikes I, Nadal-Ginard B. Resident cardiac stem cells. Cell Mol Life Sci. 2007 Mar;64(6):661-73http://doi.org/ 10.1007/s00018007-6519-y

[35] Mozaffarian D, Benjamin EJ, Go AS, Arnett DK, Blaha MJ, Cushman M, De Ferranti S, Després JP, Fullerton HJ, Howard VJ, Huffman MD. Heart disease and stroke statistics-2015 update: a report from the American Heart Association. Circulation. $2015 \quad$ Jan 27;131(4):e29-322. http://doi.org/10.1161/CIR.0000000000000152

[36] Virani SS, Alonso A, Aparicio HJ, Benjamin EJ, Bittencourt MS, Callaway CW, Carson AP, Chamberlain AM, Cheng S, Delling FN, Elkind MS. Heart disease and stroke statistics-2021 update: a report from the American Heart AssociationCirculation.2021 Feb 23;143(8):e254-e743. http://doi.org/10.1161/CIR.0000000000000950

[37] Ong SG, Wu JC. Exosomes as potential alternatives to stem cell therapy in mediating cardiac regeneration.Circ Res. 2015 Jun 19;117(1):7-9 9. http://doi.org/10.1161/CIRCRESAHA.115.306593

[38] Prathipati P, Nandi SS, Mishra PK. Stem cell-derived exosomes, autophagy, extracellular matrix turnover, and miRNAs in cardiac regeneration during stem cell therapy. Stem Cell Rev Rep. 2017 Feb;13(1):79-91.http://doi.org/ 10.1007/s12015016-9696-y

[39] Yuan MJ, Maghsoudi T, Wang T. Exosomes mediate the intercellular communication after myocardial infarction. International journal of medical sciences. 2016;13(2):113.

http://doi.org/10.1161/CIRCRESAHA.115.306593.

[40] Wang L, Zhou Y, Qian C, Wang Y. Clinical characteristics and improvement of the guideline-based management of acute myocardial infarction in China: a national retrospective analysis. Oncotarget. 2017 Jul 11;8(28):46540.http://doi.org/ 10.18632/oncotarget.14890.

[41] Vatta M. Editorial Commentary: Reprogramming autologous mesenchymal stem cells to regenerate the lost myocardium in chronic heart failure: Reboot and restore? Trends Cardiovasc Med. 2016 Jul;26(5):405-6. .

http://doi.org/ 10.1016/j.tcm.2016.02.001.

[42] Joseph J. Needling the heart to rejuvenate: the promise of intramyocardial injection of bone marrow stem cells. J Heart Lung Transplant. 2014 Jun;33(6):565-6.

http://doi.org/ 10.1016/j.healun.2014.02.029.

[43] Li SH, Sun L, Yang L, Li J, Shao Z, Du GQ, Wu J, Weisel RD, Li RK. Young bone-marrow Sca-1+ stem cells rejuvenate the aged heart and improve function after injury through PDGFRß-Akt pathway. Sci Rep. 2017 Jan 31;7:41756 .

http://doi.org/10.1038/srep41756.

[44] Li J, Li SH, Wu J, Weisel RD, Yao A, Stanford WL, Liu SM, Li RK. Young bone marrow Sca-1 cells rejuvenate the aged heart by promoting epithelial-tomesenchymal transition. Theranostics. 2018 Feb 12;8(7):1766-1781. http://doi.org/10.7150/thno.22788

[45] Schuleri KH, Feigenbaum GS, Centola M, Weiss ES, Zimmet JM, Turney J, Kellner J, Zviman MM, Hatzistergos KE, Detrick B, Conte JV. Autologous mesenchymal stem cells produce reverse remodelling in chronic ischaemic cardiomyopathy. Eur Heart J. 2009 Nov;30(22):2722-32.

http://doi.org/10.1093/eurheartj/ehp265

[46] Silva GV, Litovsky S, Assad JA, Sousa AL, Martin BJ, Vela D, Coulter SC, Lin J, Ober J, Vaughn WK, Branco RV. Mesenchymal stem cells differentiate into an endothelial phenotype, enhance vascular density, and improve heart function in a canine chronic ischemia model. Circulation. 2005 Jan 18;111(2):150-6.

http://doi.org/10.1161/01.CIR.0000151812.86142. 45

[47]Ryzhov S, Sung BH, Zhang Q, Weaver A, Gumina RJ, Biaggioni I, Feoktistov I. Role of adenosine A $2 \mathrm{~B}$ receptor signaling in contribution of cardiac mesenchymal stem-like cells to myocardial scar formation. Purinergic signalling. 2014 Sep;10(3): 477-86. http://doi.org/10.1007/s11302-014-9410-y.

[48] Vecellio $M$, Meraviglia $V$, Nanni S, Barbuti A, Scavone A, DiFrancesco D, Farsetti A, Pompilio G, Colombo GI, Capogrossi MC, Gaetano C. In vitro epigenetic reprogramming of human cardiac mesenchymal stromal cells into functionally competent cardiovascular precursors. PloS one. 2012 Dec 17;7(12):e51694. http://doi.org/ 10.1371/journal.pone. 0051694

[49] Chong JJ, Chandrakanthan V, Xaymardan M, Asli NS, Li J, Ahmed I, Heffernan C, Menon MK, Scarlett CJ, Rashidianfar A, Biben C. Adult cardiac-resident MSC-like stem cells with a proepicardial origin. Cell stem cell. 2011 Dec 2;9(6):527-40. http://doi.org/10.1016/j.stem.2011.10.002.

[50] Javazon EH, Beggs KJ, Flake AW. Mesenchymal stem cells: paradoxes of passaging. Experimental hematology. 2004 May 1;32(5):414-25. http://doi.org/10.1016/j.exphem.2004.02.004

[51] Eggenhofer E, Luk F, Dahlke MH, Hoogduijn MJ. The life and fate of mesenchymal stem cells. Front Immunol. 2014 May 19;5:148. http://doi.org/10.3389/fimmu.2014.00148 
[52] Barile L, Messina E, Giacomello A, Marbán E. Endogenous cardiac stem cells. Prog Cardiovasc Dis. Jul-Aug 2007;50(1):31-48. 2007 Jul 1;50(1): 31-48.

http://doi.org/ 10.1016/j.pcad.2007.03.005.

[53] Ferreira-Martins J, Ogórek B, Cappetta D, Matsuda A, Signore S, D'Amario D, Kostyla J, Steadman E, Ide-Iwata N, Sanada F, laffaldano G. Cardiomyogenesis in the developing heart is regulated by Ckit-positive cardiac stem cells.Circ Res. 2012 Mar 2;110(5):701-15http://doi.org/ 10.1161/CIRCRESAHA.111.259507

[54] Mazhari R, Hare JM. Mechanisms of action of mesenchymal stem cells in cardiac repair: potential influences on the cardiac stem cell niche. Nat Clin Pract Cardiovasc Med. 2007 Feb;4 Suppl1:S216.http://doi.org/ 10.1038/ncpcardio0770.

[55] Lovell MJ, Mathur A. Republished review: cardiac stem cell therapy: progress from the bench to bedside. Postgrad Med J. 2011 Aug;87(1030):558 http://doi.org/ 10.1136/pgmj.2009.192385rep.

[56] Liu CB, Huang H, Sun P, Ma SZ, Liu AH, Xue J, Fu JH, Liang YQ, Liu B, Wu DY, Lü SH. Human umbilical cord - derived mesenchymal stromal cells improve left ventricular function, perfusion, and remodeling in a porcine model of chronic myocardial ischemia. Stem Cells Transl Med. 2016 Aug;5(8):1004-

13.http://doi.org/10.5966/sctm.2015-0298

[57] Ozeki N, Muneta T, Koga H, Nakagawa Y, Mizuno M, Tsuji K, Mabuchi Y, Akazawa C, Kobayashi E, Matsumoto K, Futamura K. Not single but periodic injections of synovial mesenchymal stem cells maintain viable cells in knees and inhibit osteoarthritis progression in rats. Osteoarthritis Cartilage. 2016 Jun;24(6):1061-70 http://doi.org/10.1016/j.joca.2015.12.018

[58] Capilla-González V, López-Beas J, Escacena N, Aguilera Y, de la Cuesta A, Ruiz-Salmerón R, Martín F, Hmadcha A, Soria B. PDGF restores the defective phenotype of adipose-derived mesenchymal stromal cells from diabetic patients. Mol Ther. 2018 Nov 7;26(11):2696-2709.

http://doi.org/10.1016/j.ymthe.2018.08.011

[59] Chau MJ, Deveau TC, Gu X, Kim YS, Xu Y, Yu SP, Wei L. Delayed and repeated intranasal delivery of bone marrow stromal cells increases regeneration and functional recovery after ischemic stroke in mice. BMC Neurosci2018 Apr 12;19(1):20. http://doi.org/ 10.1186/s12868-018-0418-z.

[60] Řehořová M, Vargová I, Forostyak S, Vacková I, Turnovcová K, KupcováSkalníková $H$, Vodička $P$, Kubinová Š, Syková E, Jendelová P. A Combination of Intrathecal and Intramuscular Application of Human Mesenchymal Stem Cells Partly Reduces the Activation of Necroptosis in the Spinal Cord of SOD1G93A Rats. Stem Cells Transl Med.2019 Jun;8(6):535-547. http://doi.org/10.1002/sctm.180223

[61] Soria B, Martin-Montalvo A, Aguilera Y, MelladoDamas N, López-Beas J, Herrera-Herrera I, López E, Barcia JA, Alvarez-Dolado M, Hmadcha A, Capilla-González V. Human mesenchymal stem cells prevent neurological complications of radiotherapy. Frontiers in cellular neuroscience. 2019 May 16;13:204.

http://doi.org/10.1002/sctm.18-0223

[62] J Salgado A, L Reis R, Sousa N, M Gimble J. Adipose tissue derived stem cells secretome: soluble factors and their roles in regenerative medicine. Curr Stem Cell Res Ther. 2010 Jun;5(2):10310.http://doi.org/ 10.2174/157488810791268564

[63] Luo X, Wang H, Leighton J, O'Sullivan M, Wang P. Generation of endoderm lineages from pluripotent stem cells. Regen Med. 2017 Jan;12(1):77-89. http://doi.org/10.2217/rme-2016-0086

[64]Beltrami AP, Barlucchi L, Torella D, Baker M, Limana $F$, Chimenti S, Kasahara $H$, Rota M, Musso E, Urbanek K, Leri A, Kajstura J, Nadal-Ginard B, Anversa P: Adult cardiac stem cells are multipotent and support myocardial regeneration. Cell 2003;114:763776.

http://doi.org/10.1016/s0092-8674(03)00687-1 